\title{
Determinants The Quality of OPD Financial Statements (Empirical Study on OPD in Madura)
}

\author{
Noer Panca Mutawwab ${ }^{1 *}$, Mohamad Djasuli ${ }^{2}$, and Muhammad Syam \\ Kusufi $^{3}$ \\ 1,2,3 Trunojoyo University, Bangkalan, Indonesia
}

\begin{abstract}
There are still problems in the implementation of financial management, BPK finds as many as 10,154 and 15,434 issues containing the problems. In the acquisition of local government; The Local Government Financial Statements (LKPD) opinion Madura at year 2011-2015, only Pamekasan government increased, while Sampang and Sumenep consistently obtain Fair With Exceptions (WDP), and Bangkalan occurred a fall of LKPD opinion from Fair unqualified (WTP) to WDP. The objects of research are both the general chief and employees / financial section staff / accounting, treasurer and the author of financial statement in the Organization of Local Government (OPD) of Local Government in Madura. The used research method is quantitative method, while the sampling technique in this study is purposive sampling technique. The results of this research are the government apparatus competence has a positive effect on the quality of $O P D$ financial statement, the internal control system of government has a positive effect on the quality of OPD financial statement, the implementation of regional financial accounting system has a positive effect on the quality of OPD financial statement, the implementation of government accounting standards has a positive effect on the quality of $O P D$ financial statement, ethic has a positive effect on the quality of $O P D$ financial statement, experience has a positive effect on the quality of $O P D$ financial statement.
\end{abstract}

Keywords: quality of financial statement, the Organization of Local Government $(O P D)$

\section{INTRODUCTION}

Public accountability is the obligation of a fiduciary (agent) to provide accountability, serving, reporting, and exposing all the events and activities that are accountable to the given mandate (Principal) who has the right and authority to ask that responsibility (Mardiasmo, 2009). Financial statements are accountable to the party who has given the mandate to the government, in this case that party is the people. As what has been discussed in the theory of agency, the main principle is the existence of a working relationship between the authorized party with party receiving authority (agency). Furthermore, it can be associated that the party giving authority is the community, while the party receiving authority is a government.

Regulation of financial management itself is set in Government Regulation No. 58 Year 2005 concerning Regional Financial Management, and clarified with Regulation of Home Affair Minister No. 13 Year 2006 concerning Guidelines for

\footnotetext{
* Corresponding author. Email address: noer.panca.mutawwab@gmail.com
} 
Regional Financial Management, and complemented by Regulation of Home Affair Minister No. 59 of 2007 and Regulation of Home Affair Minister No. 21 of 2011 concerning the Amendment Regulation of Home Affair Minister No. 13, 2006.

In addition to these regulations, in order to improve and to harmonize the regional financial management, the government also established the Government Regulation No. 8 of 2006 concerning financial reporting and performance of government agencies and Government Regulation No. 24 of 2005 which has been replaced by Government Regulation No. 71 Year 2010 concerning Standard of Government Accounting. Meanwhile, in the form of accountability, the government in 2000 also issued Government Regulation No. 105 of 2000 concerning Regional Financial Management and Accountability. Furthermore, in terms of government administration, the presence of Presidential Instruction No. 7 of 1999 dated June 15, 1999 concerning Government Agency Performance Accountability (AKIP). In addition, to make the financial authority of the central government to the regions, a series of regulation also aims to further improve the accountability of the financial management in local governments.

However, the implementation of financial management, there are still some problems that occur. Audit Board of the Republic of Indonesia (BPK) discovered that 10,154 findings containing 15,434 problems. Details of the findings include 7,890 issues or $51.12 \%$ of non-compliance problems to laws and regulations in total Rp. 33.46 trillion and 7544 issues or $48.88 \%$ of the weakness of internal control system (SPI) of those non-compliance issues, there are 4,609 issues affecting the financial state / area / company recovery or financial impact worth Rp. 21.62 trillion (finance.detik.com, 05.10.2015). The results of the entire 539 The Local Government Financial Statements (LKPD) in 2014, the BPK provides Fair unqualified (WTP) opinions of 252 (47\%) LKPD, Fair With Exceptions (WDP) opinions of 247 (46\%) LKPD, Rejecting Statement to Give Opinion or Not (TMP) opinions of $35(6 \%)$ LKPD and Unusual (TW) opinions of $5(1 \%)$ LKPD (BPK RI, 2015). In the acquisition of local government; LKPD opinion Madura at year 2011-2015, only Pamekasan government increased, while Sampang and Sumenep consistently obtain WDP, and Bangkalan occurred a fall of LKPD opinion from WTP to WDP. For that, we need an improvement in the form of reporting and accountability of government over the area of local finance, especially to improve the quality of LKPD in the effort improving the LKPD opinion. These qualities include relevancy and financial statements, and those statements should be comparable and understandable. The preparation of financial statements of local government itself is a form of transparency and accountability in regional financial management, and in this case, the regional organizations have important elements in creating quality of LKPD.

Research about the quality of local financial statement has been discussed by some previous researchers, one of those studies conducted by Indriasih and Koeswayo (2014) which concluded that the competence of the government apparatus and the effectiveness of internal control influence the quality of local government financial report. As well as research conducted by Rifa'i (2014) which stated that there is an influence of ethics, competence, and experience in managing state property on the quality of the financial statement of the central government. Andini and Yusrawati (2015) which is aligned with the research Roviyantie (2011), said that the competence of the Human Resources and the implementation of 
financial accounting system affects the quality of regional financial report. Soimah (2014), mentioned the human resources capacity, utilization of information technology, internal control system of government influence on the quality of local government financial report. Yet, researcher Hapsari (2016) concluded that the application of accounting standards and internal control systems of government affect the quality of financial report.

Furthermore, researchers are interested to investigate the factors that affect the quality of the financial statement with accompanying some variables in last research. For the same purpose, here are six independent variables include the competence of government officials, internal control system of government, the implementation of local financial accounting system, the implementation of government accounting standard, ethic, and experience, while the dependent variable is the quality of the financial statement. There is still a lack of quality of BPK's opinion result about the local financial statement in three different districts in Madura, and lack of transparency in local government financial report in Madura Island as the hard finding of financial report on local financial management that should be accessible to the public as stakeholders of local finance becoming Madura as an interesting place for research to know what things are affecting the quality of financial report of local organizations.

\section{LITERATURE REVIEW / HYPOTHESES DEVELOPMENT Theory Agency}

Jensen and Meckling (1976) described the theory of agency that "agency relationship as a contract under which one or more persons (the principal (s)) engage another person (the agent) to perform some service on their behalf which involves delegating some decisions making authority to the agent". The agency theory also explained that sometimes the agency relationship also raises the problem of information imbalance or better known as the asymmetry of information, where in that case the agent or manager has more capabilities in accessing information within the enterprise.

The problem of information asymmetry is a serious matter in conveying information, especially in the agent's form of a accountability report to the principal. One of accountability report forms is one the financial statement, where the problem of information asymmetry is contrary to the good and true criteria of information accountability reports. Agent or manager can fool the principal as accountable business owners in reporting his accountability to make the report looks good and cover up the deficiencies on his performance.

Agency theory does not only exist in the private sector, but it also exists in the public sector or government. As what has been described by Zimmerman (1977), "An agency problem exists in all organizational Contexts, within firms between shareholders and management, in private clubs between management and the members, and in government between Elected and appointed Officials and the voters". The Zimmeran's opinion was also confirmed by Indriasih and Koeswayo (2014), that the agency problem did not only occur in the private sector, but also in the organization of government. Society is considered as principals giving the mandate / authority to the government as an agent in carrying out the tasks of government to improve people's welfare. It can be said that in government system, there is also a problem of information asymmetry between the society and the government. 
Asymmetry information is not in the same line with the principle and criteria of accountability report forms, especially for government financial statements, because the great financial statements must be delivered honestly, transparently, relevantly and reliably. For that reason, to achieve performance accountability, making financial government report as a government's accountability form as the principal agent to society must be qualified based on the standard of financial statement indicators which have been described before. It is intended to gain the transparent public service, and prevent the information asymmetry problem between government and the community to create a good relations and mutual support between the two of them.

\section{Financial Statement}

The financial statement is the end product of a process of recording and summaring business transaction data. Basically, the financial statement is the result of the accounting process that can be used as a tool to communicate the financial data or the company activities to the interested parties (Hery, 2016: 3). Meanwhile, the Government Accounting Standards known as Government Regulation No. 71 of 2010 (2012: 47) explains that the financial statement is a structured report about the financial position and transactions undertaken by a reporting entity. The financial statement of the public sector is an important financial position based on transactions conducted by public sector organizations (Sujarweni, 2015: 88). According to Bastian (2010: 297), explained that the financial statement of public sector is a representation of the financial position of the transactions carried out by a public sector entity.

The general purpose of financial statement is to provide information about the financial position, the realization of the budget, balance budget, cash flow, results of operations, and changes in equity of a reporting entity which is useful to users in making and evaluating decisions about the allocation of resources (SAP, 2012: 47). According to Madiasmo (2009: 163-164), the details of accounting purpose and financial statement of government organizations are:

1) providing financial information to determine and predict cash flow, balance sheet, and the need for short-term financial resources government unit.

2) Providing financial information to determine and predict the economic conditions of a government unit and the changes occurred in it.

3) providing financial information to monitor the performance, its compliance to the laws, contracts that have been agreed, other conditions that have been required

4) providing information for planning and budgeting, as well as to predict the effect of the acquisition and allocation of resources towards the operational achievement

5) Providing information to evaluate the material and organizational performance Based on Government Accounting Standards known as Government Regulation No. 71 of 2010 (2012: 48-49), it states that the components contained in one set of financial statement consist of budget execution report and financial statement, so that all components become :

a) Realized budget report;

b) Over budget changes report;

c) Balance Sheet;

d) Operational report; 
e) Cash flow report;

f) Equity changes report

g) Financial statement note.

\section{Quality of Financial Statement}

According to the Government Regulation No. 71 of 2010 regarding the Government Accounting Standards, it explains the qualitative characteristics of financial statement are normative measurements needing to be realized in the accounting information to complete its purpose. The government financial statement is qualified if it has some characteristics, include : (1) reliable, (2) relevant, (3) understandable, (4) comparable.

Quality of financial report is crucial in the acceptance of BPK opinion. Based on Law No. 15 of 2004 regarding State Finance of Check, Management and Responsibility, opinion is a professional statement as examiner conclusion about the fairness level of the information presented in the financial statement. According to the decision of the BPK No. 4/K/I-XIII.2 /9/2012 paragraph 13 regarding the opinion type, there are four types of opinion, include; (1) Fair unqualified (WTP), (2) Fair With Exceptions (WDP), (3) Unusual (TW), (4) Rejecting Statement to Give Opinion or Not (TMP). While the criteria for giving opinion is internal control system, compliance, the adequacy of disclosure in the Financial Statement (LK) and LK conformity to SAP (BPK RI, 2013).

However, according to the Government Accounting Standards Board in Rifa'i (2014) mentioned some indicators in the good financial statement of public sector which were :

1) Accounting for the implementation of its functions, the financial statement describing honestly about all transactions and other events that should have been presented

2) Result of surgery done in one full period completing the normative requirements include relevancy, reliable, trustworthy, and comparable to get the opinion from an external audit unconditionally (WTP)

3) Financial condition Report presented transparently could be easily understood, and accounted

4) Reporting condition of long-term resources that can help in making decision, and activities related to finance in the next period

\section{Factors that Affect Quality of OPD Financial Statements}

a) Government Apparatus Competence

Work competence is the work ability of each individual covering aspects of knowledge, skills, and attitude which are convenient to the set standard (Law No. 13 of 2003). Whereas, according to Suraida, she said that competence is the professional skills possessed by an employee as a result of formal education, participation in training, seminar, symposia and others (Rifa'i, 2014). Agoes and Ardana argued that competence and skills in capability means running a job or profession. In a wider sense, competence includes the mastery of knowledge and skills for adequate, having a good attitude and behavior is needed to do the job or profession (Indriasih and Koeswayo, 2014).

Human resource competence includes its capacity which is the ability of a person or an individual, an organization, or a system to carry out its functions or 
powers to achieve its purposes effectively and efficiently. Capacity should be seen as the ability to achieve the performance, to produce the outputs and outcomes (Roviyantie in Setyowati et al., 2016). Competence is the character or motives of both individuals and organizations to achieve superior job performance (Kasim, 2015).

\section{b) Internal Control System of Government}

Internal control is a continuous process of an organization aiming to obtain the trust to guarantee the safety of resources which will be done by all management elements within the organization. Mahmudi said that the internal control system which is an integral process in action and activities done continuously by the management and the entire staff to provide assurance on the achievement of organizational goals by effective and efficient activities, the reliability of financial reporting, the security of state assets, and compliance to the law (Indriasih and Koeswayo, 2014).

According to Tetuan et al, (2006) in Indriasih and Koeswayo (2014), identified three main objectives in designing an effective system of internal control, include: (1) the reliability of financial reporting, (2) the effectiveness and efficiency of company operations, and (3) compliance to the laws and regulations. The effectiveness of internal control of government in according to the Government Regulation 60 of 2008 including; (1) the control environment, (2) risk assessment, (3) control activities, (4) information and communication, and (5) internal control monitoring.

\section{c) Implementation of Regional Financial Accounting System}

Information system is a set of related components which serves to collect, process, store, and distribute information to support the creation of satisfaction and oversight within the organization (Laudon in Mulyono, 2009). Information system is usually based on computer that helps users to change data into an information quickly and accurately. Regional financial information system is based on Government Regulation No. 56 of 2005, which is a system having function to record, administer, and process the data of regional financial management and other relevant data into information presented to the public and as an consideration in making decisions in planning, execution, and reporting of regional government accountability.

The regional financial accounting system is an accounting system that includes the process of recording, classification, interpretation, concising of transactions, or financial events and financial reporting in purpose of implementation of the budget, its implementation followed the accounting principles generally accepted by public (Regulation of Home Affair Minister No. 29 of 2002). Following the Regulation of Home Affair Minister No. 13 of 2006, the local government financial accounting system includes a series of procedures starting from data collection, recording, until the financial reporting in the context of accountability of the budget that can be done manually or using a computer application.

\section{d) Implementation of The Government Accounting Standards}

Based on Government Regulation No. 71 Year 2010, which explained that the Government Accounting Standards (SAP) is the accounting principles applied 
in preparing and presenting the financial statement of the government. According to Udiyanti stated that the application of government accounting standard can give a positive influence to the quality of financial information report of government aiming to realize a clean and respectable government.

Santoso (2008) in Hapsari (2016), explained that government accounting standard is needed for the financial statement created by the government can be compared, and making the same perception and understanding between presenters financial statement, the financial statement users and the financial statement supervisors. Additionally, government accounting standards are beneficial to complete the information needs generally and more qualified for financial statements users in order to assess accountability and economic, social, and political decision-making,.

e) Ethic

Ethic is the most important thing in life even in the work. Ethic also plays an important role in all professions. According to Stead et al, ethic is a set of moral principles separating a good thing and a bad thing and what should be done and should not be done by someone (Koerniawan, 2013). In contrast, according to Munawir, ethic is a moral and behavioral principles that became the fondation for someone's acts, so what he does is a commendable action to increase the degree of dignity and honor for someone (Koerniawan, 2013).

And Rifa'i (2014) also mentioned the ethical indicators include:

1. Working with full devotion and responsibility

2. Behaving ethically

3. Keeping the personal good name, employer, institute.

4. Upholding the morality at work.

It can be concluded that the work ethic is a basic principle of a person in separating the good and bad things based on the needs and experiences to determine what action will be taken to increase the degree of dignity and honor. And the existence of roles and position make a person can determine their own work ethic.

\section{f) Experience}

Experience is a learning process and increasing the development potency of good behavior from the formal and non-formal education could be interpreted as a process taking people to the higher pattern of behavior (Sari, 2011). Purnamasari (2005) in Asih (2006), concluded that an employee who has a high work experience will have advantages in several things including; 1). Detecting errors, 2). Understanding error and 3) Finding cause of the error.

Their workers who have work experience are expected to get jobs related to their expertise. The longer a person in employment in accordance with the expertise, the more expected to increase productivity (Mahendra, 2014).

Framework of the concept of the factors affecting the quality of the financial statements of regional organizations in regional organizations throughout Madura will be shown bellow; 


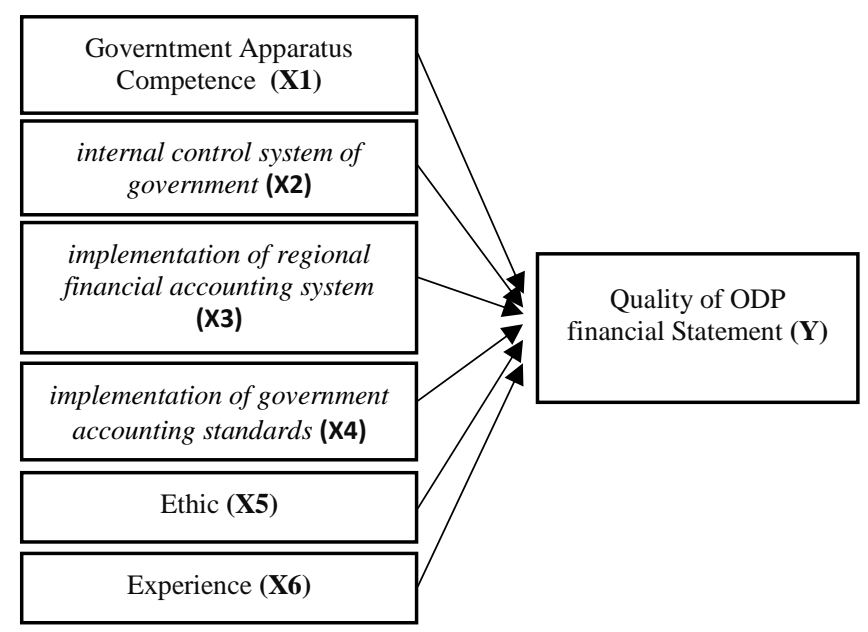

Figure 1 Framework Research

\section{Hypothesis Development \\ Relation of Government Apparatus Competence on The Quality of Financial Statements}

Based on agency theory standpoint, reliability and presentation of financial statement that are easy to understand and be accountable requires the ability and competence of human resources are adequate. It can be said that the better competencies and capabilities of the compilers of the financial statement, the better quality of the resulting financial statement. So the hypothesis is:

H1: government apparatus competence has positive effect on the quality of financial report.

\section{Relation of Internal Control System Government on The Quality of Financial Statements}

The financial statements were qualified to be delivered by honest, transparent, relevant, reliable and trustworthy. Based on agency theory standpoint, to achieve a transparent financial statements, relevant and trustworthy require control measures carried out by all the security elements in the organization so that available resources can be guaranteed. It can be said that the better the internal control of the run, the better the quality of the resulting financial statements. So the hypothesis is:

$\mathrm{H} 2$ : Internal control system of government positive effect on the quality of financial statements.

\section{Relation of Regional Financial Accounting System Implementation on The Quality of Financial Statement}

Quality report to be delivered by honest, transparent, relevant, reliable and trustworthy. Based on agency theory viewpoint to achieve the financial statements are reliable and trustworthy, the financial statements should describe truthfully all 
transactions and other events that should have been presented as well as the financial statements must be accurate. Through the utilization of financial management information system, is expected to further improve the accuracy of the information accountability of local governments, especially in improving the quality of financial reports generated. It can be said that the better the area of financial accounting system you run, the better the quality of the resulting financial statements. So the hypothesis is:

H3: Implementation of regional financial accounting system positive effect on the quality of financial statements.

\section{Relation of Government Accounting Standards Implementation on The Quality of Financial Statements}

The financial statements were qualified to be delivered by honest, transparent, relevant, reliable and trustworthy. To reach the report that is relevant, reliable, comparable and accountable finance the preparation must be in accordance with the accounting principles applied and generally acceptable or in accordance with accounting standards. So we can say that the preparation of financial statements apropriate with SAP, then the quality reports generated, So the hypothesis is:

H4: Implementation of government accounting standards positive effect on the quality of financial statements.

\section{Relation of Ethics on The Quality of Financial Statements}

Statements quality and to avoid asymmetry of information between the public and the government, agency theory explains that the financial statements should describe truthfully all transactions, trustworthy and accountable. Someone who has a good ethics will always run the good and leave the bad so that anything that can be done reliably and will always be responsible to the fullest. The basic principle of a person in separating the good things and the bad things that can determine what action will be expected to improve the work and duties. It can be said with more and better ethics owned financial report's authors, the better the quality of financial reporting is done. Then, the hypothesis is:

H5: Ethics positive effect on the quality of financial statement.

\section{Relation of Experience on The Quality of Financial Statements}

quality of financial statements must be submitted with an honest, transparent, relevant, reliable and trustworthy. Based on agency theory standpoint, reliability and presentation of financial statements can be accounted requires human power and skills gained from previous experience. It can be said that the longer and more experience possessed by the finance officer, the better the quality reports generated. So the hypothesis is:

H6: Experience positive effect on the quality of financial statetement 


\section{RESEARCH METHODS}

This study uses a quantitative research approach. Data used in the study of primary data that the questionnaire. The questionnaire is a technique of data collection is done by giving a set of questions or a written statement to the respondent to answered (Sugiyono, 2016: 142).

\section{Population and Sample}

According Arikunto (2010), Population is the subject of research, are partially or representative sample of the population studied. The population in this study is the regional organizations in local governance regencies in Madura. While the sample in this study is the Head and Employees / Staff the Finance / Accounting, Treasurer and Financial Statements Composer in regional organizations district in Madura.

The sampling technique in this study usingtechnique is purposive sampling, and sampling criteria in this study as well as the Chief Officer / Staff the Finance / Accounting, Treasurer and Financial Statements Drafting of OPD in the government district in Madura. And questionnaires carried out directly by the researcher to the respondents. Measurement opinions of respondents in the research instrument using 5-point scale Likert.

\section{Data Analysis Techniques}

Data analysis techniques in this study using SPSS 20. The data processing is done by means of SPSS, which is then the result of processing the data using SPSS will be analyzed.

\section{a. Data Quality Test}

\section{1) Validity Test}

Validity test is a valid form of testing to measure or invalidity of data a questionnaire. Validity test can use the correlation coefficient Pearson correlation. A statement said to be valid when the $r$ count $\geq r$ table for degree of freedom $(\mathrm{df})=\mathrm{n}-2$ (Ghozali, 2013: 45). And the data is said to be valid if the correlation between scores of each of the questions with a total score of each construction significant at the 0.05 or 0.01 level then the question is as valid (Ghozali, 2016: 55).

\section{2) Reliability Test}

Reliability test using in measuring a questionnaire which is an indicator variable. Validity test is measured by a statistical test Cronbach's Alpha $(\alpha)$, which is a construct or a variable is said to be reliable if the value of Cronbach's Alpha> 0.70 (Nunnally, 1994 in Ghozali, 2013: 48)

\section{b. Classical Assumption Test}

\section{1) Normality Test}

According Ghozali (2013), Normality test aims to test whether the residuals of the model regression have a normal distribution. KolmogorovSmirnov Test (KS) is a statistical analysis that can show the data distribution. Basis for a decision in the KS test as follows If significant value $>0.05$, so normal distribution.

\section{2) Multicolinearity Test}

Multicolinearity test conducted to test whether there is a correlation between independent variables (independent) in the regression model. Each independent variable value > tolerance 0.10 , or equal to the value of Variance Inflation Factor <10 (Ghozali, 2013).

\section{3) Heterokedastisitas Test}


Testing heterokedastisitas in this study using white test. White test, this test is done with regressed the residuals squared $\left(U^{2} t\right)$ with independent variables, the independent variable squares and multiplication (interaction) independent variables. Results Recourse will produce $R^{2}$ are used to calculate $c^{2}$ where $c^{2}=\mathrm{n} \times R^{2}$, If $c^{2}$ count $<c^{2}$ tables, so their alternative hypothesis of heteroscedasticity in the model is rejected (Ghozali, 2016: 138-139).

\section{c. Analysis of Multiple Regression}

Multiple Regression this study to test the hypothesis 1 to hypothesis 6 , the hypothesis was that examines the effect of the competence of the government apparatus competence, the internal control system of government (SPIP), implementation of regional financial accounting system, implementation of government accounting standards, ethics, and experience on the quality of financial statements.

\section{1) Coefficient of Determination}

Ghozali (2013: 97) explains that the coefficient of determination is used to measure the ability of a model in explaining the variation of the independent variable.

\section{2) Partial test (t test)}

Ghozali (2013) t statistical test to show how far the influence of the explanatory variables / independent individually in explaining the variation of the dependent variable.

\section{RESULT}

In this study, data analysis and testing is done using SPSS version of 20. The results of the data analysis of test result data quality, classic assumption test results, and results of inferential statistical analysis in the form of regression analysis, coefficient of determination, and hypothesis testing.

\section{Data Quality Test Results}

\section{1) Validity Test}

Test the validity of this research using the correlation coefficient Pearson correlation. As ever revealed Ghozali, A questionnaire considered valid if the statements in the questionnaire were able to reveal something that will be measured by the questionnaire. A statement said to be valid when the $r$ count $\geq r$ table for degree of freedom $(\mathrm{df})=\mathrm{n}-2$ (Ghozali, 2013: 45). the validity of the test results of 75 respondents Instrument questions used for variable the government apparatus competence (X1) with 10 questions, variable internal control systems of government (X2) with nine questions, the variable Implementation of regional financial accounting system (X3) with 10 questions, the variable implementation of government accounting standards (X4) with 6 questions, variable ethics (X5) with 10 questions, variable experience (X6) with 8 questions, and the variable the quality of OPD financial statements (Y) with 11 questions declared invalid because of Pearson Correlation or $r$ count larger than $r$ table. With the value of $r$ tables provided by $(\mathrm{df})=\mathrm{n}-2$, which is equal to 0.227 (75-2 $=73$ with alpha $5 \%$ (twotailed test). It is also seen from the significant value is a significant level of 0.05 or 0.01 . It can be concluded that all the statements in the questionnaire were able to measure the variables expected and considered valid. 


\section{2) Reliability Test}

Reliability test was conducted to measure the consistency of the answers of respondents, so it can be seen reliable and reliability a questionnaire. Reliability testing is measured by a statistical test Cronbach's Alpha $(\alpha)$, Nunnaly explainned a construct or a variable is said to be reliable if the value of Cronbach's Alpha $>0.70$. Here can be seen the reliability test results in this study:

Table 1 Reliability Test Results

\begin{tabular}{lccc}
\hline \multicolumn{1}{c}{ Variable } & $\begin{array}{c}\text { Cronbach's } \\
\text { Alpha }(\boldsymbol{\alpha})\end{array}$ & $\begin{array}{c}\text { Reability } \\
\text { Limit }\end{array}$ & Specification \\
\hline Government Apparatus Competence (X1) & 0,870 & 0,70 & Reliable \\
Internal Control System of Government (X2) & 0,881 & 0,70 & Reliable \\
Implementation of The Regional Financial & 0,923 & 0,70 & Reliable \\
Accounting System (X3) & & & \\
Implementation of Government Accounting & 0,871 & 0,70 & Reliable \\
Standards (X4) & 0,799 & 0,70 & Reliable \\
Ethics (X5) & 0,879 & 0,70 & Reliable \\
Experiences (X6) & 0,846 & 0,70 & Reliable \\
Quality of OPD Financial Statements (Y) &
\end{tabular}

From the calculation of the test results, showing that the value of Cronbach's Alpha $(\alpha)$ for each variable the quality of OPD financial statements (Y), Government apparatus competence (X1), internal control system of government (X2), implementation of regional financial accounting system (X3), implementation of government accounting standards (X4), Ethics (X5), and experience (X6) that is $>0.70$. Thus it can be concluded that the statements of all variables proved to be reliable.

\section{Classical Assumption Test Results}

\section{1) Normality Test}

Normality Test is used to test whether the residuals of the regression model has a normal distribution. As for how that can be done to detect whether or not residual that is normally distributed with statistical analysis. Kolmogorov-Smirnov Test (KS) is a statistical analysis that can show the data distribution. As explained Ghozali, If significant value $>0.05$ then normal distribution and vice versa if the significant value $<0.05$ then the distribution is not normal. Here normality test results in this study presented in Table 2:

Table 2 Normality Test Results

\begin{tabular}{lcl}
\hline & $\begin{array}{c}\text { Unstandardized } \\
\text { Residual }\end{array}$ & Description \\
\hline Kolmogorov-Smirnov Z & 0,809 & Normal \\
Asymp. Sig. (2-tailed) & 0,529 & \\
\hline
\end{tabular}

Based on the above test results can be seen from the Kolmogorov-Smirnov value of 0.809 and the significant value of 0.529 . From the data normality test results showed a significantly greater value than $5 \%$ or $>0.05$ so that it can be said the results had residual normal distribution. And it can be concluded that the results of the residuals of the regression equation in this study had to meet the assumptions of normality. 


\section{2) Multicolinearity Test}

Multicolinearity Tests conducted to test whether there is a correlation between independent variables. The value of tolerance and Variance Inflation Factor (VIF) showed independent variables satiap Which explained by the other independent variables. As explained Ghozali, if each independent variable has a value $>$ tolerance 0.10 , or equal to the value of VIF $<10$ then it can be said not happen Multicolinearity. In summary the results of the test Multicolinearity in this study are presented in the following table:

Table 3 Test Results Multicolinearity

\begin{tabular}{|c|c|c|c|}
\hline Variable & Tolerance & VIF & Description \\
\hline Government Apparatus Competence (X1) & 0.451 & 2.218 & $\begin{array}{c}\text { Not Happen } \\
\text { Multicolinearity }\end{array}$ \\
\hline Internal Control System of Government (X2) & 0.399 & 2.509 & $\begin{array}{l}\text { Not Happen } \\
\text { Multicolinearity }\end{array}$ \\
\hline $\begin{array}{l}\text { Implementation of The Regional Financial } \\
\text { Accounting System (X3) }\end{array}$ & 0.382 & 2.620 & $\begin{array}{l}\text { Not Happen } \\
\text { Multicolinearity }\end{array}$ \\
\hline $\begin{array}{l}\text { Implementation of Government Accounting } \\
\text { Standards (X4) }\end{array}$ & 0.387 & 2.584 & $\begin{array}{l}\text { Not Happen } \\
\text { Multicolinearity }\end{array}$ \\
\hline Ethics (X5) & 0.430 & 2.327 & $\begin{array}{l}\text { Not Happen } \\
\text { Multicolinearity }\end{array}$ \\
\hline Experiences (X6) & 0.568 & 1.761 & $\begin{array}{l}\text { Not Happen } \\
\text { Multicolinearity }\end{array}$ \\
\hline
\end{tabular}

Based on the test results presented table 3 , we can see the results of calculation of the value of Tolerance and VIF. Of all the variables none of the value tolerance of less than 0.10 or values Tolerance of all variables $>0.10$. Likewise all the independent variables no VIF's value that exceeds 10 or VIF $<10$. It can be concluded that in this study did not happen multikolinieritas.

\section{3) Heteroskidastity Test}

Ghozali (2013: 139), a test used to examine the inequality Heteroskidastity variance of the residuals of the observations to other observations, if it occurs in common then called homoskedastisitas and if the variance of the residuals of the observations to other observations different then called heteroscedasticity. In addition Ghozali also mentioned that a good regression model is a model that homoskedastisitas or not they develop symptoms heteroskedastisitas. Testing can be done with heteroskedastisitas a test white. White test done by regressed the residuals squared $\left(U^{2} t\right)$ with independent variables, the independent variable squares and multiplication (interaction) independent variables. The regression results will produce $R^{2}$ are used to calculate $c^{2}$, where $c^{2}=\mathrm{nx} R^{2}$. If $c^{2}$ count $<c^{2}$ tables, hence their alternative hypothesis of heteroscedasticity in the model is rejected (Ghozali, 2016: 138-139). Here are the results of tests that useheteroskedastisitas test white in this study:

Table 4 Test Results Heteroskidastity with Test White

\begin{tabular}{ccc}
\hline Model & R Square & Sig. \\
\hline 1 & 0.131 & 0.751 \\
\hline
\end{tabular}

Based on the above table it can be seen that the results of the regression residuals squared $\left(U^{2} t\right)$ with independent variables, the independent variable 
squares and multiplication (interaction) independent variables, $R^{2}=0.131$. Furthermore, do the calculations to obtain $c^{2}$ is calculated by the formula $c^{2}=\mathrm{n} \mathrm{x}$ $R^{2}$. The number of observations (n) of 75. So it can be in the know $c^{2}=75 \times 0.131$, then $c^{2}$ count equal to 9.825. As for $c^{2}$ tables in this research note $\mathrm{df}=5$ (df $=\mathrm{K}$ 1 ), with $\alpha=0.05, c^{2}$ table at 11.070. It can be concluded that the model in this study did not happen heteroskedastisitas, since $c^{2}$ count $<c^{2}$ tables.

\section{Regression Analysis}

Multiple Regression selected as the independent variable in this study consist of 6 variables or more than one. As revealed by Ghozali (2013), Regression (multiple regression) to test more than one independent variable (metric). The regression model in this study was to test the effect of independent variables Government Apparatus Competence (X1), the Internal Control System of Government (X2), Implementation of Financial Accounting System (X3), Implementation of Government Accounting Standards (X4), Ethics (X5), and experience (X6) on the dependent variable quality of OPD financial statements (Y). Regression analysis was used to determine the effect of independent variables are (X1X2X3X4X5X6) on the dependent variable (Y), it can be calculated using linear regression analysis. The results of the testing of multiple linear regression using SPSS version 20 as follows:

Table 5 Results of Linear Regression

\begin{tabular}{cc}
\hline Model & Regression Coefficients \\
\hline 1 (Constant) & 3.105 \\
X1 & 0.192 \\
X2 & 0.172 \\
X3 & 0.170 \\
X4 & 0,244 \\
X5 & 0.213 \\
X6 & 0.158 \\
\hline
\end{tabular}

From the results regression analysis testing variable in determining the quality of OPD financial statements, can be expressed by the equation is linear as follows:

$$
\begin{gathered}
Y=b_{0}+b_{1} X_{1}+b_{2} X_{2}+b_{3} X_{3}+b_{4} X_{4}+b_{5} X_{5}+b_{6} X_{6} \\
Y=3.105+0.192 X 1+0.172 X 2+0.170 X 30.244 X 4+0.213 X 5+0.158 X 6
\end{gathered}
$$

Description:

$$
\begin{aligned}
& \text { Y = Quality of Financial Statements OPD } \\
& \mathrm{b} 0 \quad=\text { constant } \\
& \mathrm{b}_{1,} \mathrm{~b}_{2} \mathrm{~b}_{3}, \mathrm{~b}_{4} \mathrm{~b}_{5} \mathrm{~b}_{6} \quad=\text { Regression coefficients } \\
& \mathrm{X} 1=\text { Government Apparatus Competence } \\
& \mathrm{X} 2=\text { Internal Control System of Government } \\
& \text { X3 = Implementation of Regional Financial Accounting System } \\
& \text { X4 = Implementation of Government Accounting Standard } \\
& \text { X5 } \quad \text { Ethics } \\
& \text { X6 }=\text { Experience }
\end{aligned}
$$

From multiple linear regression equation above can be explained that:

1. the constant value 3.105. This indicates that the value of the variable the quality of financial statements as a dependent variable of 3.105 without the influence Government Apparatus Competence (X1), Internal Control System 
of Government (X2), Implementation of Regional Financial Accounting System (X3), Implementation of Government Accounting Standards (X4), Ethics (X5), and experience (X6).

2. Regression coefficient value of the independent variable government apparatus competence (X1) is 0.192 . The coefficient value means if the value of the independent variable government apparatus competence (X1) is increased by one unit, it will cause an increase in the value of the dependent variable is the quality of OPD financial statements (Y) of 0.192 units. In this case it is assumed that the value of the other independent variables are constant.

3. Regression coefficient values of the independent variables internal control system of government (X2) is 0.172 . The coefficient value means if the value of the independent variable internal control system of government (X2) is increased by one unit, it will cause an increase in the value of the dependent variable is the quality of OPD financial statements (Y) equal to 0.172 units. In this case it is assumed that the value of the other independent variables are constant.

4. Regression coefficient value of the independent variable Implementation of Regional Financial Accounting System (X3) is 0.170. The coefficient value means if the value of the independent variable Implementation of Regional Financial Accounting System (X3) is increased by one unit, it will cause an increase in the value of the dependent variable is the quality of OPD financial statements (Y) equal to 0.170 units. In this case it is assumed that the value of the other independent variables are constant.

5. Regression coefficient value of the independent variable implementation of government accounting standards (X4) is 0.244 . The coefficient value means if the value of the independent variable implementation of government accounting standards (X4) is increased by one unit, it will cause an increase in the value of the dependent variable is the quality of the financial statements (Y) amounted to 0.244 units. In this case it is assumed that the value of the other independent variables are constant.

6. While the value of the regression coefficient of the independent variable ethics (X5) is 0.213 . The coefficient value means if the value of the independent variable ethics (X5) is increased by one unit, it will cause an increase in the value of the dependent variable is the quality of the financial statements (Y) equal to 0.213 units. In this case it is assumed that the value of the other independent variables are constant.

7. Regression coefficient value of the independent variable experience (X6) is 0.158 . The coefficient value means if the value of the independent variable experience (X6) increased by one unit, it will cause an increase in the value of the dependent variable is the quality of the financial statements (Y) equal to 0.158 units. In this case it is assumed that the value of the other independent variables are constant.

\section{Coefficient Determination Results}

The coefficient of determination test by Ghozali (2013), used to measure the ability of a model in explaining the variation of the independent variable. While the value of the coefficient of determination alone are between zero and one, so that when thevalue adjusted $R$-square is close to zero then the ability of 
independent variables to explain the variation of the dependent variable can be said to be limited. Instead extent close to one, then the independent variable provide almost all the information needed to predict the dependent variable variation. Here are the results of coefficient determination test in this study:

Table 6 Test Coefficient of Determination

\begin{tabular}{cc}
\hline Model & Adjusted R Square \\
\hline 1 & 0.766 \\
\hline
\end{tabular}

Based on the test results table coefficient of determination above, it can be seen that the value of Adjusted $R$-Square close to one or amounted to 0.766 . It can be concluded that $76.6 \%$ of the variation magnitude of the quality of OPD the financial statements can be explained by the independent variables Government Apparatus Competence (X1), Internal Control System of Government (X2), Implementation of Regional Financial Accounting System (X3), Implementation of Government Accounting Standards (X4), Ethics (X5), and experience (X6). While $23.4 \%$ is explained by other variables outside of the research model.

\section{Partial Test (t Test)}

Testing of partial or $\mathrm{t}$ statistical test performed to show how far the influence of the explanatory variables / independent individually in explaining the variation of the dependent variable (Ghozali, 2013). T test results in this study describe in the following table:

Table 7 Test Results Partial or $\mathrm{t}$ test

\begin{tabular}{lccc}
\hline \multicolumn{1}{c}{ Variable } & t & Sig. & Description \\
\hline Government Apparatus Competence (X1) & 2.286 & 0.025 & Significant \\
Internal Control System of Government (X2) & 2.029 & 0.046 & Significant \\
Implementation of Regional Financial & 2.182 & 0.033 & Significant \\
Accounting System (X3) & & & \\
Implementation of Government Accounting & 2.010 & 0.048 & Significant \\
Standards (X4) & 2.090 & 0.040 & significant \\
Ethics (X5) & 2.044 & 0.045 & significant \\
Experience (X6)
\end{tabular}

According to the table above can be seen on the partial test $t$, variable Government Apparatus Competence (X1) is t count 2.286 larger than t table 1.667 and 0.025 significant values $(<0.05)$. Thus the first hypothesis which states "The government apparatus competence positive effect on the quality of financial statements" fullysupported. So from the analysis shows that the government apparatus competence significant positive effect on the quality of OPD financial statements.

In the Internal Control System of Government (X2) t count 2.029 larger than $\mathrm{t}$ table of magnitude 1.667 and 0.046 significant value or significant value $<0.05$. Thus the second hypothesis which states "the Internal Control System of Government positive effect on the quality of OPD financial statements" fullysupported. So from the results of the analysis showed that the Internal Control System of Government significant positive effect on the quality of OPD financial statements. 
For variable Implementation of Regional Financial Accounting System (X3) $\mathrm{t}$ count 2,182 larger than t table 1.667 and 0.033 significant value or significant value $<0.05$. Thus the third hypothesis which states "The Implementation of Regional Financial Accounting System positive effects the quality of OPD financial statements" fullysupported. So from the analysis showed that implementation of regional financial accounting system significant positive effect on the quality of OPD financial statements.

The results of the $t$ variable Implementation of Government Accounting Standards (X4) counted 2,010 larger than t tables magnitude of 1.667 and 0.048 significant value or significant value $<0.05$. Thus the fourth hypothesis which states "The Implementation of Government Accounting Standards has positive effect on the quality of OPD financial statement" fullysupported. So from the analysis shows that the implementation of government accounting standards significant positive effect on the quality of OPD statements.

While the results variable Ethics (X5) $t$ count 2.090 larger than $t$ tables magnitude of 1.667 and significant value of 0.040 or significant value $<0.05$. Thus the fifth hypothesis which states "Ethics positive effect on the quality of OPD financial statements" fullysupported. So from the results of the analysis showed that the Ethics positive effect on the quality of OPD financial statements.

And also for the variable experience (X6) t count 2.044 bigger than t tables magnitude of 1.667 and 0.045 significant value or significant value $<0.05$. Thus the sixth hypothesis which states "Experience positive effect on the quality of OPD financial statements" fullysupported. So from the results of the analysis showed that experience positive effect on the quality of OPD financial statements.

\section{DISCUSSION}

\section{Relations Government Apparatur Competence on the Quality of Financial Statement}

According Suraida, competence is the professional skills possessed by an employee as a result of formal education, participation in training, seminars, symposia and others (Rifa'i, 2014). Agoes and Ardana argues, competence and skills in capability means running a job or profession. In a broader sense, competence includes the mastery of knowledge and skills for adequate, has a good attitude and behavior to do the job or profession (Indriasih and Koeswayo, 2014).

Competence of adequate human resources and quality berkuantitas and will increase the value of information in the financial statements of the government. Tausikal (2007), explains that the financial statements must be prepared by personnel who have competence in the field of financial management and accounting system, which can lead to financial information useful to the user (Indriasih and Koeswayo, 2014).

Government apparatus competence is the ability and pengatahuan owned by civil servants and government employees to carry out the duties and responsibilities assigned to him by the provision of education, training and sufficient experience in government agencies in particular parts or finance. Government apparatus competence measured by indicators of knowledge, skills and attitudes. Based on the answers of respondents on average educated Bachelor with a percentage of more than $50 \%$, namely $69 \%$ and $23 \%$ of them educated Master or Doctor, as well as the background of education Accounting 31\%, can be said to be capable and 
sufficient to carry out his duties in an employee in finance and the preparation of OPD financial statements. The higher education will then have the knowledge, skills and abilities and attitudes that can be relied upon in preparing the OPD financial statements.

Based on analysis shows the variable Government Apparatus Competence (X1) t count 2.286 larger than t table 1.667 and 0.025 significant values $(<0.05)$. Thus the first hypothesis which states "The government apparatus competence positive effect on the quality of financial statements" fullysupported. Based on these results indicate that the better the competencies and capabilities of the apparatus of government in preparing the financial statements, the better the quality of the resulting financial statements.

The results of this study are also consistent with research conducted by Roviyantie (2011), which are reinforced by Andini and Yusrawati (2015) by stating that the Human Resource Competency have a significant impact on the quality of the region's financial statements. Rifa'i (2014) states that competence in managing state property affects the quality of the financial statements of the central government. And in accordance with Indriasih and Koeswayo (2014), which states that the government apparatus competence affect the quality of financial statements.

\section{Relations of Internal Control System Government on the Quality of Financial Statements}

Internal control is a continuous process of an organization that aims to obtain reasonable assurance will ensure the safety of existing resources is done by all elements of management personnel within the organization (Kasim, 2015). According to Tetuan et al, (2006) in Indriasih and Koeswayo (2014), identifies three main objectives in designing a system of effective internal control, namely: (1) the reliability of financial reporting, (2) the effectiveness and efficiency of company operations, and (3) compliance with laws and regulations. The effectiveness of internal control seeks to provide reasonable assurance for the achievement of organizational goals through effective and efficient, the reliability of reporting the use of the budget, safeguarding assets, and compliance with laws and regulations. It can be said that by implementing the internal control system will be able to improve the reliability and quality of OPD financial statements. And internal control systems of government can be measured by indicators of the control environment, risk assessment, control activities, information and communication, and monitoring of internal control.

Based on analysis of variable Internal Control System Government (X2), t count 2.029 larger than t table 1.667 and 0.046 significant value or significant value $<0.05$. Thus the second hypothesis which states "the internal control system government is a positive effect on the quality of OPD financial statements" fullysupported. This shows that the better the internal control system of government, can making the better the quality of OPD financial statements.

The results of this study are consistent with previous studies that Soimah (2014), which states the internal control system of government a significant effect on the quality of OPD financial statements. In line with the research Indriasih and Koeswayo (2014), which concluded that the effectiveness of internal controls affect the quality of financial reporting. Likewise with Hapsari study (2016), which mentions the internal control system affects the quality of financial statements. 


\section{Relation of Regional Financial Accounting System Implementation on The Quality of Financial Statement}

Usually computer-based information systems that assist users in converting data into an information quickly and accurately. The area of financial accounting system is an accounting system that includes the process of recording, classification, interpretation, peringkasan transactions, or financial events and financial reporting in the framework of implementation of the budget, implemented in accordance with accounting principles generally acceptable (Kepmendagri Number 29 year 2002). The system is also aimed at strengthening the perception systems and procedures in the area of financial management and the interpretation of the implementation of various laws and regulations. With the application made by the Directorate General of Local Finance Circular of the Ministry of Internal Affairs with the Ministry of Interior No. SE.900 / 122 / BAKD which aims to speed up data transfer so that the area of financial data collection more efficient. Measurement of the area of financial accounting system implementation can be measured by indicators of identification, classification, their control systems to ensure reliability, and calculate the effect of each operation. Through the application of financial management information system, it can be said will further improve the accuracy of the information accountability of local governments, especially in improving the quality of financial reports generated.

Based on the analysis of the variable $t$ Implementation of Regional Financial Accounting System (X3) worth 2,182 larger than t table 1.667 and 0.033 significant value or significant value $<0.05$. Thus the third hypothesis which states "The implementation of regional financial accounting system positive effects the quality of OPD financial statements" fullysupported. The results showed that the better the impelementation of regional financial accounting system, the better too the quality of the OPD financial statements. These results are consistent with research Roviyantie (2011) which states, implementation of regional financial accounting systems significantly influence the quality of financial reporting area. as well as research conducted Andini and Yusrawati (2015), the application area of financial accounting systems significantly influence the quality of financial statements.

\section{Relation of Government Accounting Standards Implementation on the Quality of Financial Statements}

Government Accounting Standards (SAP) is the accounting principles applied in preparing and presenting financial statements (PP No. 71 Year 2010). According Udiyanti stated that the application of government accounting standards can provide a positive influence on the quality of financial reporting information so that the government will realize a clean and respectable government. Meanwhile, according to Bastian, Reports on the financial accountability of government that meets the principles on time and prepared to follow government accounting standards generally accepted is one of the measures taken to achieve transparency and accountability of public finance management (Hapsari, 2016). Furthermore, it can be explained by the implementation of government accounting standards will affect the quality of OPD financial statements. Measurement of SAP implementation can be seen through the indicator antaralain accounting basis, the historical value, realization, substance over fair value, perioderitas, consistency, full disclosure, presentation of financial statements.

Based on the analysis, the value $t$ count of the variable implementation government accounting standards (X4) worth $2.010>\mathrm{t}$ table 1.667 and 0.048 
significant value or significant value $<0.05$. Thus the fourth hypothesis which states "The implementation of government accounting standards has positive effects on the quality of OPD financial statements" fullysupported. The results showed that the corresponding preparation of financial statements with SAP, the more quality of resulting research. Result of report is in line with research conducted by the (2016) which concluded that the implementation government accounting standards directly affects the quality of financial statements.

\section{Relation of Ethics on the Quality of Financial Statements}

Ethics is a set of moral principles that separate a good thing and a bad thing and what should be done and should not be done by someone (Koerniawan, 2013). Each individual has their own concept in determining ethics on him in accordance with the role and position bears. Through the explanation of the basic principles of a person in separating the good things and the bad things that can determine what action will be expected to improve the work and duties. Likewise related to the financial statements, the ethics of good workers is expected to improve the quality of financial statements. Measurement ethics measured through indicators: work with full dedication and responsibility, behave according to the code of ethics, maintain a good name to the person, employer, and institutions, uphold morals in doing the job.

Based on the analysis, the value of t count the variable Ethics (X5) is worth 2.090 bigger than $t$ table which magnitude of 1.667 and significant value of 0.040 or significant value $<0.05$. Thus the fifth hypothesis which states "Ethics positive effect on the quality of OPD financial statements" fullysupported. The analysis showed that the better ethics owned financial statement's authors, the better the quality of financial reporting is done. This is in line with previous studies that research conducted Rifa'i (2014), explain that ethics in managing state property affects the quality of the financial statements of the central government.

Relation of Experiences on the Quality of Financial Statements

Based on the demographics of respondents, the average experience in working on a long time work 8-11 years with a number of 23 respondents or $31 \%$, and the fewest respondents who have worked 12-15 years with the number 5 or $7 \%$ respondents. While the remaining 20 respondents in each work 1-3 years old and 4-7 years old or $27 \%$, and $9 \%$ or 7 respondents with working time $>15$ years. It is very supportive of the research for the respondents who have averaged more could be represented in a variable experience. Purnamasari (2005) in Asih (2006), concluded that an employee who has a high work experience will have advantages in Several things Including; 1). Detecting errors, 2). Understanding error and 3) Finding cause of the error. Meanwhile, According to Amron, more experience earned by a worker will the make getting trained and skilled workers to do the job. The longer a person in employment in accordance with the expertise it is expected to increase of productivity (Mahendra, 2014). With increasing experience, the level of quality of the work is expected to be better. Measurement indicators in this study experience, among others: Old work, complexity of the problem / issue, Continuity of work, amount of work done.

Based on the analysis, the value of $t$ count variable experience (X6) is worth $2.044>t$ table 1.667 and 0.045 significant value or significant value $<0.05$. Thus the sixth hypothesis which states "the Experiences positive effect on the quality of OPD financial statements" fullysupported. These results indicate that longer and a lot of experience possessed by the finance officer, the better the quality of the 
resulting financial statements. This is in line with research conducted by Rifa'i (2014), which states that the experience in managing state property affects the quality of the financial statements of the central government.

\section{CONCLUSION}

This research was conducted with the purpose to determine the effect of the government apparatus competence, the internal control system of government, the implementation of regional financial accounting system, the implementation of government accounting standards, ethics, and experience on the quality of OPD financial statements. Testing this study using multiple regression with SPSS version 20 . The results of the analysis of this study concluded that:

1) Government apparatus competence positive effect on the quality of OPD financial statements. This explains that the better the competency of government apparatus, especially in matters of financial statements the better the quality of OPD financial statements generated.

2) Internal control system of government positive effect on the quality of OPD financial statements. This explains that with the better the government's internal control system operated by OPD, the better the quality of the financial statements of the OPD is generated.

3) Implementation of regional financial accounting system positive effect the quality of OPD financial statements. This explains that the better the area of financial accounting system that is owned and run the OPD the better the level from quality of OPD financial statements generated.

4) Implementation of government accounting standards positive effect on the quality of OPD financial statements. This explains that increasingly adhered to and applied to government accounting standards in the OPD, the better the level of quality of financial statements produced by OPD.

5) Ethics positive effect on the quality of OPD financial statements. This explains that the more the better ethics constituent owned financial statements in OPD the better the quality of the financial statements produced by OPD.

6) Experience positive effect the quality of OPD financial statements. This explains that the longer and more work experience employees have in finance and the preparation of OPD financial statements, the better the quality of financial statements produced by OPD.

\section{References}

Andini, D., \& Yusrawati. (2015). Pengaruh Kompetensi Sumber Daya Manusia dan Penerapan Sistem Akuntansi Keuangan Daerah Terhadap Kualitas Laporan Keuangan Daerah. Jurnal Ekonomi, Manajemen dan Akuntansi I, 24 (1), Juni 2015.

Asih, D. A. T. (2006). Pengaruh Pengalaman Terhadap Peningkatan Keahlian Auditor Dalam Bidang Auditing. Essay. Universitas Islam Indonesia

Arikunto, S. (2010). Prosedur Penelitian: Suatu Pendekatan Praktik, Edisi Revisi, Cetakan Ke-14. Jakarta: Rineka Cipta 
Bastian, I. (2010). Akuntansi Sektor Publik: Suatu Pengantar. Jakarta: Erlangga

BPK RI. (2013). Ikhtisar Hasil Pemeriksaan Semester II Tahun 2012. Buku II Pemeriksaan Keuangan. Jakarta

BPK RI. (2015). Laporan Tahunan 2015 Badan Pemeriksa Keuangan Republik Indonesia. Jakarta Pusat

Darmawan, D. (2014). Metode Penelitian Kuantitatif. Bandung: PT Young Rosdakarya.

Gatra, S. (2015). BPK: Tata Kelola Laporan Keuangan Pemerintah Daerah Masih Banyak Masalah. (Online). http://nasional.kompas.com/read/2015/05/04/20210071/BPK.Tata.Kelola.La poran.Keuangan.Pemerintah.Daerah.Masih.Banyak.Masalah (diakses 11 Maret 2017 Pukul 17.47 WIB)

Ghozali, I. (2013). Analisis Multivariate Dengan Program IBM SPSS 21, Edisi 7. Semarang: Badan Penerbit Universitas Diponegoro.

Ghozali, I. (2016). Aplikasi Analisis Multivariate Dengan Program IBM SPSS 23, Edisi 8. Semarang: Badan Penerbit Universitas Diponegoro.

Hapsari, B. D. (2016). Anteseden Kualitas Laporan Keuangan Dan Implikasinya Terhadap Akuntabilitas Kinerja Instansi Pemerintah Daerah. Essay. Institut Agama Islam Negeri Surakarta.

Hery. (2016). Analisis Laporan Keuangan: Integrated and Comprehensive Edition. IKAPI. Jakarta: PT Grasindo

Indriasih, D., \& Koeswayo, P. S. (2014). The Effect Of Government Apparatus Competence And The Effectiveness Of Government Internal Control Toward The Quality Of Financial Reporting And Its Impact On The Performance Accountability In Local Government (Survey Of All Units Local Government In Tegal City - Central Java Province- Indonesian). South East Asia Journal Of Contempory Business, Economics and Law, 5 (1), December 2014.

Jensen, M. C., \& Meckling, W. H. (1976). Theory Of The Firm: Managerial Behavior, Agency Cost And Ownership Structure. Journal of Financial Economics 3. North-Holland Publishing Company.

Kasim, E. Y. (2015). Effect Of Government Accountants Competency And Implementation Of Internal Control To The Quality Of Government Financial Reporting. International Journal of Business, Economics and Law, 8 (1), Dec 2015.

Koerniawan, K. A. (2013). Etika Dalam Problematika Di Era Competitif Menurut Sisi Pandang Akuntan Publik. Jurnal MODERNISASI, 9 (1), Februari 2013. 
Mahendra, A. D. (2014). Analisis Pengaruh Pendidikan, Upah, Jenis Kelamin, Usia dan Pengalaman Kerja Terhadap Produktivitas Tenaga Kerja (Studi Di Industri Kecil Tempe Di Kota Semarang). Essay. Diponegoro University.

Mardiasmo. (2009). Akuntansi Sektor Publik. Yogyakarta: Andi Yogyakarta.

Mulyono, I. (2009). Uji Empiris Model Kesuksesan Sistem Infomasi Keuangan Daerah (SIKD) Dalam Rangka Peningkatan Transparansi Dan Akuntabilitas Keuangan Daerah. Jurnal. Palembang : Simposium Nasional Akuntansi 12.

Nurviasari, R., \& Riharjo, I. B. (2016). Pengaruh Sistem Informasi, Komitmen Manajemen, Budaya Organisasi Terhadap Akuntabilitas Kinerja Instansi Pemerintah. Jurnal Ilmu dan Riset Akuntansi, 5 (4), April 2016.

Pratama, A. H. (2015). BPK Temukan 15.000 Masalah di Laporan Keuangan Pemerintah. (online).https://finance.detik.com/berita-ekonomi-bisnis/d3036450/bpk-temukan-15000-masalah-di-laporan-keuangan-pemerintah (diakses 11 Maret 2017 Pukul 17.59 WIB)

Rifa'i, A. B. (2014). Pengaruh Etika, Kompetensi, Dan Pengalaman Dalam Mengelola Barang Milik Negara Terhadap Kualitas Laporan Keuangan Pemerintah Pusat. Essay. Universitas Negeri Yogyakarta.

Roviyantie, D. (2011). Pengaruh Kompetensi Sumber Daya Manusia dan Penerapan Sistem Akuntansi Keuangan Daerah Terhadap Kualitas Laporan Keuangan Daerah. Jurnal. Program Studi Akuntansi Fakultas Ekonomi Universitas Siliwangi.

Sari, N. N. (2011). Pengaruh Pengalaman Kerja, Independensi, Objektivitas, Integritas, Kompetensi Dan Etika Terhadap Kualitas Audit. Essay. Universitas Diponegoro

Sarwono, J. (2006). Metode Penelitian Kuantitatif Dan Kualitatif. Yogyakarta: Graha Science.

Setyowati, L., Isthika, W., \& Pratiwi, R. D. (2016). Faktor-Faktor Yang Memepengaruhi Kualitas Laporan Keuangan Pemerintah Daerah Kota Semarang. Jurnal KINERJA, 20 (2), 179-191.

Soimah, S. (2014). Pengaruh Kapasitas Sumber Daya Manusia, Pemanfaatan Teknologi Informasi dan Sistem Pengendalian Intern Pemerintah Terhadap Kualitas Laporan Keuangan Pemerintah Daerah Kabupaten Bengkulu Utara. Essay. Universitas Bengkulu.

Sugiyono. (2016). Metode Penelitian Kuantitatif, Kualitatif, dan R\&D, Cetakan $K e-23$. Bandung: Alfabeta.

Suwarjeni, V. W. (2015). Akuntansi Sektor Publik: Teori, Konsep, dan Aplikasi. Yogyakarta: Pustaka Baru Press.

Zimmerman, J. L. (1977). The Muunicipal Accounting Maze: An Analysis of Political Incentives. Journal of Accounting Research, 15. (online).https://www.jstor.org (diakses 6 Mei 2017 pukul 11.54 WIB) 
, Intruksi Presiden Republik Indonesia Nomor 7 Tahun 1999 tanggal 15 Juni 1999 tentang Akuntabilitas Kinerja Pemerintah.

, Keputusan Menteri Dalam Negeri Nomor 29 Tahun 2002 tentang Pedoman Pengurusan, Pertanggungjawaban dan Pengawasan Keuangan Daerah Serta Tata Cara Penyusunan Anggaran Pendapatan dan Belanja Daerah, Pelaksanaan Tata Usaha Keuangan Daerah dan Penyusunan Perhitungan Anggaran Pendapatan dan Belanja Daerah.

, Peraturan Menteri Dalam Negeri Nomor 13 Tahun 2006 tentang Pedoman Pengelolaan Keuangan Daerah.

, Peraturan Menteri Dalam Negeri Nomor 21 Tahun 2011 tentang Perubahan Kedua Atas Peraturan Dalam Negeri Nomor 13 Tahun 2006 tentang Pedoman Pengelolaan Keuangan Daerah.

, Peraturan Pemerintah Republik Indonesia Nomor 8 Tahun 2006 tentang Pelaporan Keuangan Dan Kinerja Instansi Pemerintah.

, Peraturan Pemerintah Republik Indonesia Nomor 18 Tahun 2016 tentang Perangkat Daerah.

, Peraturan Pemerintah Republik Indonesia Nomor 56 Tahun 2005 tentang Sistem Informasi Keuangan Daerah

, Peraturan Pemerintah Republik Indonesia Nomor 58 Tahun 2005 tentang Pengelolaan Keuangan Daerah

, Peraturan Pemerintah Republik Indonesia Nomor 60 Tahun 2008 tentang Sistem Pengendalian Intern Pemerintahan (SPIP)

, Peraturan Pemerintah Republik Indonesia Nomor 71 Tahun 2010 tentang Standar Akuntansi Pemerintahan. 2012. Bandung: Fokusmedia

, Peraturan Pemerintah Republik Indonesia Nomor 105 Tahun 2000 tentang Pengelolaan dan Pertanggungjawaban Keuangan Daerah

, Undang-Undang Republik Indonesia Nomor 5 Tahun 2014 tentang Aparatur Sipil Negara

, Undang-Undang Republik Indonesia Nomor 13 Tahun 2003 tentang Ketenagakerjaan.

, Undang-Undang Republik Indonesia Nomor 15 Tahun 2004 tentang Pemeriksaan Pengelolaan dan Tanggungjawab Keuangan Negara.

www.kemendagri.go.id

www.surabaya.bpk.go.id 